\title{
Eloge: Owsei Temkin, 6 October 1902-18 July 2002
}

\section{Citation}

Rosenberg, Charles E. 2004. Eloge: Owsei Temkin, 6 October 1902-18 July 2002. Isis 95(3): 451-453.

\section{Published Version}

doi:10.1086/428966

\section{Permanent link}

http://nrs.harvard.edu/urn-3:HUL.InstRepos:4730330

\section{Terms of Use}

This article was downloaded from Harvard University's DASH repository, and is made available under the terms and conditions applicable to Other Posted Material, as set forth at http:// nrs.harvard.edu/urn-3:HUL.InstRepos:dash.current.terms-of-use\#LAA

\section{Share Your Story}

The Harvard community has made this article openly available.

Please share how this access benefits you. Submit a story.

Accessibility 
team and the team's all-time assist leader. In remembering him, one of Gerry's students found in this early distinction an apt metaphor for Gerry's extraordinary qualities as a teacher. He was a master of the assist, of finding a way, by word or example, to enable a student to move to the next level of knowledge, confidence, or achievement. It was, in this student's words, "a subtle and giving art." For those of us fortunate enough to know Gerry as a teacher, that insight will stand out in memory with special clarity, alongside his many services to the profession and to his university. For all of us there is the living presence of his scholarship.
1. I would like to thank Angela Creager and the Program in History of Science, Princeton University, for making available to me the written memories and appreciations of Gerry gathered after his death.

\section{Department of History \\ University of California \\ Berkeley, California 94720-2550}

(C) 2004 by The History of Science Society. All rights reserved. 0021-1753/2004/9503-0006\$10.00

\section{OWSEI TEMKIN, 6 OCTOBER 1902-18 JULY 2002}

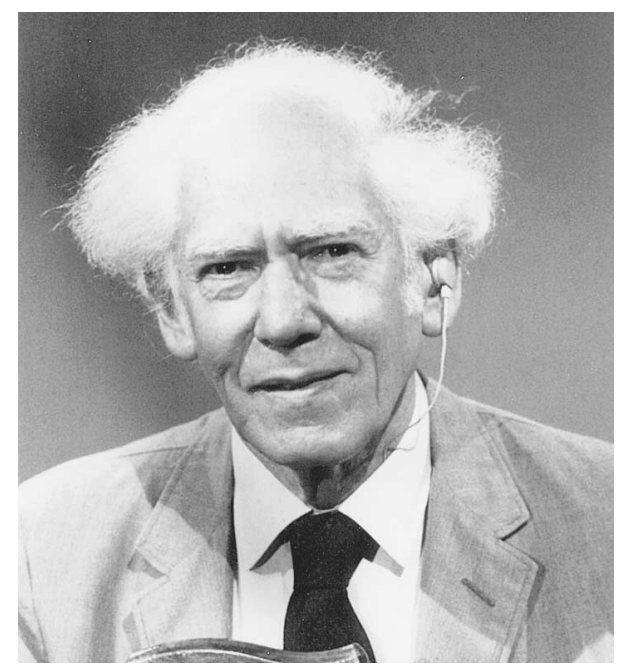

Owsei Temkin died on 18 July 2002 at the age of ninety-nine. He was generally regarded as the leading medical historian of the past century. Publishing in every decade between the 1920s and the present, Temkin observed-and participated-as the history of medicine evolved from an ancient if gentlemanly occupation into a selfconscious academic subdiscipline. His range of interests was extraordinary-from classical antiquity through the twentieth century, from surgery to physiology. Temkin was a careful and extraordinarily thoughtful reader of texts in a dozen languages and a sophisticated and critical interpreter, expert at placing those texts in precise historical contexts. At the same time, he sought to retain medical history as a branch of medicine-relevant to the clinician in his or her capacity as problem solver and moral actor. In this sense he remained a humanist and amateur, a seeker after meaning rather than disciplinary status.

Temkin was born in Minsk, Russia (now Byelorussia), on 6 October 1902 and moved to Germany with his father and mother, Samuel and Anna Temkin, in 1905. After attending primary school and Gymnasium in Leipzig, he studied medicine at the University of Leipzig, where he received the M.D. in 1927; after a year of internship he turned to the university's Institute for the History of Medicine, where he served as Assistent (1928-1932) and then Privatdozent before migrating to the United States in 1932 . He accompanied his chief, Henry Sigerist, when the latter-with remarkable prescience-left to assume the directorship of the Johns Hopkins University's new Leipzig-influenced and Rockefeller-endowed Institute for the History of Medicine. ${ }^{1}$ Temkin remained at Hopkins until his retirement in 1968. Or at least his formal retirement; he remained in Baltimore, a productive writer and scholar into his nineties.

Until the exodus of refugees from Hitler's Germany, the history of medicine in America had been, as I have indicated, an often enthusiastic but almost entirely avocational-parttime-activity. The cohort of Henry Sigerist and his younger students and associates Ludwig Edelstein, Erwin H. Ackerknecht, and Temkin brought a German sense of disciplinary commitment and seriousness of vocational purpose to the United States. ${ }^{2}$ (One should add the name of George Rosen-American born but German trained - to this group.) Hearing impaired and a bit reserved in manner, Temkin was perhaps the most personally diffident among this influential cadre of historians, but very likely the scholar who was to exert the largest ultimate influence 
on his field's professionalization. And yet, ironically, Temkin remained concerned about the seeming alienation of an increasingly professional and numerous body of medical historians from practicing clinicians and their everyday concerns - and the displacement of physician historians by non-medically trained holders of the doctorate. He nevertheless played a significant role in that very disciplinary evolution he found so disquieting - as intellectual leader at the Johns Hopkins institute, as longtime editor of the Bulletin of the History of Medicine, as builder of bridges to the history of science, and-perhaps most importantly-as an exemplar of scholarly range, subtle analysis, and leadership in the framing of agenda-setting questions.

Temkin had originally sought—as he recalled in The Double Face of Janus - to study philosophy in connection with medicine, but he discovered that this eclectic combination was impossible in the German academy. He chose medicine as his vocation but never lost interest in "philosophy." Indeed, the central theme in his historical work was his commitment to a philosophical-moral and humanistic — view of the medical enterprise. It is a project that in one of its dimensions might be seen as surfacing in recent years in the rather more policy-oriented form of bioethics. More significantly, from the historian's point of view, Temkin's approach implied a focus on meaning as contextual and thus on the historical and geographic specificity of the clinical encounter. Although not inaccurately represented as a historian of ideas, Temkin was in a way quite the opposite. He studied explanatory concepts - often the substance of our only surviving documentary evidence-but, I would argue, fundamentally in an effort to understand a period's assumptions and perceptions and thus, in a measure, the clinical choices facing doctors and patients. Even when he focused on periods remote in time, or dissected the intellectual debates of philosopher-physiologists, Temkin never lost sight of the interaction between clinical and biological realities and the ideas employed in understanding and rationalizing them. Thus, for example, his extremely influential essay "Surgery and the Rise of Modern Medical Thought" (1951) emphasizes the surgeon's clinical tasks and institutional setting in the shift to a lesion-oriented, specific conception of disease. Theories of disease might in a parallel way reflect the prevailing ecology of disease: thus the malaria so common in classical Greece might well have influenced notions of disease periodicity and climatic influences. Similarly, the seventeenth-century incidence of epidemic infectious disease - and especially plague-almost certainly influenced Thomas Sydenham's emphasis on both a specific and ontological view of disease and the role of particular configurations of place and climate in the shaping of an "epidemic constitution." The coherence of Temkin's best-known book, his magisterial-and still definitive-The Falling Sickness: A History of Epilepsy from the Greeks to the Beginnings of Modern Neurology (1945; 2nd rev. ed., 1971), rests on this very counterpoint between epilepsy as biopathological and social event and the changing system of ideas though which frightening and seemingly uncanny seizures were construed in different times and places. In his hands, the history of ideas became a tool for cultural history-not an abstract and decontextualized end in itself. The same might be said of his elegant and now-classic study of Galenism and its historical fortunes. ${ }^{3} \mathrm{He}$ was influenced as well by contemporary notions of uniquely configured and integrated cultural regimes characteristic of particular times and places. Medicine was both a component of such historically specific worldviews and necessarily a product of them. Temkin was not only a moral but an intellectual and social cosmographer. The meanings of sickness and health, of theraputics and death, could not be understood outside particular configurations of society and culture. They constituted an aspect of history and were its outcome. For Temkin-as for his friend Norbert Eliashumanism, like cultural analysis, implied historicism. There can be no medicine without meaning, and meaning is always situated-and thus historical.

Medicine, as Owsei Temkin both argued and demonstrated, constitutes a particularly revealing site for the study of the human condition in its necessarily precise social and temporal settings. "Modern physics," he explained on one occasion, "boastfully or plaintively speaks of the meaningless universe. But there is no meaningless universe in medicine. Human beings are not satisfied with viewing health and disease as matters of mere chance separable from their lives." For better or worse, medicine will always be a cultural indicator-and constituent. ${ }^{4}$ It is no accident that Temkin's works are still read, that problems he identified are still alive. His scholarship linked medicine, history, and philosophy in a necessary and seamless way. Yet his conclusions were complex and often ironic, never shrill and didactic. In the words of his longtime friend Erwin H. Ackerknecht, it was neither Temkin's extraordinary scholarship nor his 
sharply honed analytic abilities that set him aside from his peers, but what Ackerknecht called wisdom. It is a quality always in short supply. ${ }^{5}$

1. The biographical data is cited from Temkin's own c.v., deposited with his extensive and invaluable papers at the Alan Mason Chesney Medical Archives of the Johns Hopkins Medical Institutions, Baltimore, Maryland. Owsei Temkin, "The Double Face of Janus," in The Double Face of Janus and Other Essays in the History of Medicine (Baltimore/ London: Johns Hopkins Univ. Press, 1977), pp. 3-37, provides a revealing autobiographical reflection. See also Gert Brieger, "Temkin's Times and Ours: An Appreciation of Owsei Temkin," Bulletin of the History of Medicine, 2003, 77:1-11; Charles E. Rosenberg, "What Is Disease? In Memory of Owsei Temkin," ibid., pp. 491-505; and "Owsei Temkin at Eighty," ibid., 1982, 56:311-316.

2. For relevant background see Thomas Rütten, "Karl Sudhoff and 'the Fall' of German Medical History," in Locating Medical History: The Stories and Their Meanings, ed. Frank Huisman and John Harley Warner (Baltimore/London: Johns Hopkins Univ. Press, 2004), pp. 95-114; and Vivian Nutton, "Ancient Medicine: From Berlin to Baltimore," ibid., pp. 115-138.
3. Owsei Temkin, Galenism: The Rise and Decline of a Medical Philosophy (Ithaca, N.Y.: Cornell Univ. Press, 1973). A similar cultural contextualism shapes Temkin, Hippocrates in a World of Pagans and Christians (Baltimore/London: Johns Hopkins Univ. Press, 1991)_published, it should be noted, in Temkin's late eighties.

4. Owsei Temkin, "An Historical Analysis of the Concept of Infection," in Double Face of Janus (cit. n. 1), pp. 465-471, on p. 471. This passage is adapted from Rosenberg, "What Is Disease?" (cit. n. 1), p. 505.

5. Erwin H. Ackerknecht, review of The Double Face of Janus, Gesnerus, 1977, 34:421-424, quoting from p. 424: "Temkin nicht nur ein ausserordentlicher Gelehrter und scharfsinniger Denker ist, sondern etwas besitzt, was selten ist and was wir auf englisch 'wisdom' nennen.

Charles E. RosenberG

Department of the History of Science

Harvard University

Science Center 227

Cambridge, Massachusetts 02138

(C) 2004 by The History of Science Society. All rights reserved. 0021-1753/2004/9503-0007\$10.00

\section{SUSAN ELIZABETH ABRAMS, 27 JULY 1945-29 JUNE 2003}

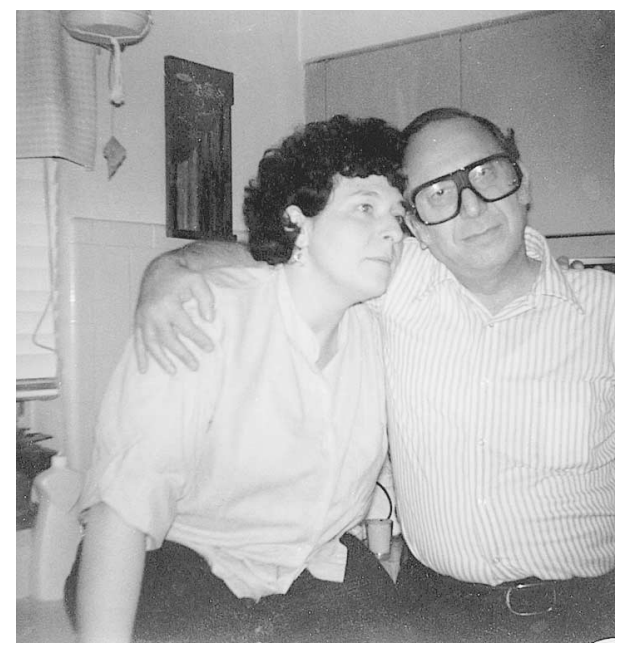

Susan Abrams was my editor at the University of Chicago Press; but more than that, she was my friend. Susan grew up in St. Louis, Missouri, where she attended Washington University and majored in English literature. During her senior year, she drew a blank when writing her thesis on Norman Mailer's An American Dream. The turmoil of the Vietnam era occupied her more than her studies. In some desperation, she did the thing that became second nature during her years as an editor: after some effort in securing his phone number, she called Mailer, who was obviously surprised, yet delighted and kind enough to speak for an hour with the enterprising and politically engaged student. She finished her thesis, which displayed a sharp authorial touch in its conclusions. After some odd jobs, Susan was hired as an editor at C. V. Mosby, a medical publisher in St. Louis.

Susan arrived at the University of Chicago Press in 1979 to become the ninth science editor in ten years. She would stay for a quarter of a century, turning a lackluster list into something 